\title{
ANALISIS SALURAN PEMASARAN JAMBU KRISTAL (psidium guajava l.) DI DESA SIDOREJO KECAMATAN PURWOHARJO KABUPATEN BANYUWANGI
}

\author{
MARKETING CHANNELANALYSIS OF CRYSTAL GUAVA (Psidium guajava L.) \\ IN SIDOREJO VILLAGE, PURWOHARJO DISTRICT, BANYUWANGI REGENCY
}

\author{
MOH. AJI PRASETYO*, AGUS SUPRIONO \\ Fakultas Pertanian Universitas Jember \\ *Email: ajiprasetyo317@gmail.com
}

\begin{abstract}
ABSTRAK
Penelitian ini dilakukan dengan merumuskan masalah (a) saluran pemasaran jambu biji kristal, (b)margin pemasaran yang paling kecil (c) nilai farmer share yang paling besar, (d) saluran pemasaran jambu kristal yang paling menguntungkan, (e) saluran pemasaran yang paling efisien pada saluran pemasaran jambu biji kristal di Desa Sidorejo Kecamatan Purwoharjo kabupaten Banyuwangi. Penentuan lokasi dilakukan dengan purposive method di Desa Sidorejo. Metode penentuan sample dengan purposive sampling sebanyak 32 petani. Metode penelitian menggunakan deskriptif analitik. Dimana saluran pemasaran dan fungsi lembaga pemasaran dianalisis menggunakan analisis deskritif, dan marjin pemasaran serta efisiensi pemasaran dianalisisi mengggunakan analisis marjin pemasaran dan efisiensi pemasaran. Hasil penelitian menunjukkan 1) terdapat 4 saluran pemasaran dengan 2 model saluran pemasaran .2) marjin pemasaran pada saluran pemasaran 1 sebesar Rp. 5.500 untuk semua grade, dengan nilai share keuntungan bagi petani sebesar 32,43\% (grade A), dan 19,35\% (grade B), dan marjin pada saluran pemmasaran 2 sebesar Rp. 7.500 untuk semua grade, marjin pemasaran pada saluran pemasaran 3 sebesar Rp.5.500 dengan nilai share keuntungan bagi petani sebesar $45 \%$ untuk grade A dan 29,36\% untuk grade B, dan marjin pemasaran pada saluran 4 sebesar Rp.5500 dengan nilai share keuntungan sebesar 43,30\% untuk petani. 3). Nilai efisiensi saluran pemasaran untuk grade A dan B pada saluran 1 sebesar 14,60\%, dan 18,39\%, pada saluran 3 sebesar $12,90 \%$, dan $16,68 \%$, dan pada saluran pemasaran 4 nilai efisiensi pemasaran sebesar $14,08 \%$.
\end{abstract}

Kata Kunci : jambu kristak, pemsaran, efisiensi pemasaran

\begin{abstract}
This research was conducted by formulating the problem of (a) crystal guava marketing channel, $(b)$ the smallest marketing margin (c) the largest farmer share value, (d) the most profitable crystal guava marketing channel, (e) the most profitable marketing channel. the most efficient marketing channel for crystal guava in Sidorejo Village, Purwoharjo District, Banyuwangi Regency.

Determination of the location is done by purposive method in Sidorejo Village. The method of determining the sample by purposive sampling as many as 32 farmers. The research method uses descriptive analytic. Where marketing channels and marketing agency functions are analyzed using descriptive analysis, and marketing margins and marketing efficiency are analyzed using marketing margin and marketing efficiency analysis.

The results of the research show 1) there are 4 marketing channels with 2 marketing channel models. 2) the marketing margin on marketing channel 1 is Rp. 5,500 for all grades, with a profit share value for farmers of $32.43 \%$ (grade A), and 19.35\% (grade B), and a margin on marketing channel 2 of Rp. 7,500 for all grades, marketing margin on marketing channel 3 is Rp. 5,500 with profit share value for farmers of $45 \%$ for grade $A$ and $29.36 \%$ for grade B, and marketing margin on channel 4 is $R p .5500$ with profit share value by $43.30 \%$ for farmers. 3). The value of marketing channel efficiency for grades $A$ and $B$ in channel 1 is $14.60 \%$, and $18.39 \%$, in channel 3 is $12.90 \%$, and $16.68 \%$, and in marketing channel 4 the value of marketing efficiency is $14,08 \%$.
\end{abstract}

Keyword: Crystal guava, marketing, marketing efficiency 


\section{PENDAHULUAN}

Jambu biji Psidium guajava L, sebagaimana dinyatakan oleh Andayani (2014), sangat diminati di Indonesia karena jambu biji kaya akan kandungan vitamin dan mineralnya. Buah jambu biji bisa dikonsumsi dalam keadaan segar ataupun dengan berbagai olahan, seperti halnya entuk jus jambu biji, sirup jambu biji, ataupun manisan jambu biji. Jambu biji juga sangat dikenal oleh masyarakat Indonesia dan tersebar luas di berbagai daerah di Indonesia. Jambu biji, ditegaskan oleh Hadiati dan Leni (2015), mempunyai banyak manfaat bagi kesehatan sehingga banyak dicari konsumen, baik di dalam negeri maupun di luar negeri. Oleh karena itu jambu biji merupakan salah satu tanaman hortikultura yang memiliki peluang dan potensi untuk diekspor guna menghasilkan devisa.

Diyakinkan oleh Parimin (2005), jambu biji memiliki kandungan vitamin $\mathrm{C}$ yang cukup tinggi. Kandungan vitamin $\mathrm{C}$ yang terkandung dua kali lebih banyak dari pada kandungan vitamin $\mathrm{C}$ pada buah jeruk manis yang hanya $49 \mathrm{mg}$ per $100 \mathrm{~g}$. Kandungan lain yang terdapat pada $100 \mathrm{~g}$ buah jambu biji antara lain adalah protein sebanyak 0,9g, lemak 0,3g, karbohidrat $12,2 \mathrm{~g}$, kalsium $14 \mathrm{mg}$, fosfor $28 \mathrm{mg}$, besi 1,1mg, vitamin A 25S1, vitamin B1 0,02 $\mathrm{mg}$, vitamin C 87mg, dan air 86g dengan total kalori sebanyak 49 kalori. Jambu biji, juga diyakinkan oleh Hadiati dan Leni (2015), juga memiliki kasiat seperti mengurangi gejala diare, mengurangi resiko kanker prostat dan payudara, membantu menurunkan berat badan, menyeimbangkan kadar gula dara pada penderita diabetes, menghaluskan kulit, dan masih banyak lagi.

Jambu biji, lanjut Hadiati dan Leni (2015), pertama kali di temukan di Amerika Tengah oleh Nikolai Ivanovich Vavilov pada tahun 1887 hingga 1942. Kemudian penyebaran jambu biji meluas ke Asia Tenggara dan ke wilayah Indonesia melalui Tahiland. Lebih jauh Darmayanti (2018) menyatakan, lebih dari 150 negara telah membudidayakan jambu biji, di antaranya: Jepang, India, Taiwan, Malaysia, Brasil, Australia, Filipina, serta Indonesia. Iklim di Indonesia sangat cocok dalam pembudidayaan jambu biji ini.

Pengembangan jambu biji di Indonesia, menurut Parimin (2005), dewasa ini tercatat sudah berkembang dengan pesat. Konsumsi jambu biji kini tidak hanya untuk memenuhi kebutuhan konsumsi rumah tangga, namun sudah meluas hingga masuk pasar non rumah tangga seperti supermarket, hotel, restoran, 
serta industri hasil pengolahan. Besarnya pangsa pasar jambu biji di Indonesia ini membuat produksi jambu biji memiliki kecenderungan angka rata-rata pertumbuhan yang positif, atau cenedrung mengalami peningkatan dari tahun ke tahun

Bentuk jambu biji yang ditanam di Indonesia, diyakinkan oleh Andayani (2014), bermacam-macam. Ada yang bulat, agak lonjong, dan lonjong. Warna daging buahnya ada yang putih dan merah. Jambu biji ini pun ada yang memiliki banyak biji dan bahkan tidak memiliki biji. Adapun jenis jambu biji yang dibudidayakan di Indonesia adalah jambu pasar minggu, jambu Palembang, jambu Getas Merah, jambu Australia, jambu Farang, jambu Sukun, jambu Bangkok, jambu Kamboja, jambu Tukan, jambu Mutiara, dan "yang baru jambu biji Kristal Taiwan”.

Sebagaimana yang diungkapkan oleh Mahendra (2017), saat ini jambu biji dengan varietas yang berbeda mulai di budidayakan di Indonesia, yaitu jambu biji Kristal Taiwan dan mulai diminati masyarakat. Dinyatakan oleh Wiraatmaja (2017), jambu biji kristal pertama kali ditemukan pada tahun 1991 di Distrik Kao Shiung - Taiwan dan merupakan bentuk mutasi dari jambu Muangthai Pak. Menurut Mahendra (2017), di Indonesia tanaman jambu biji Kristal telah dibudidayakan secara komersial sejak tahun 1998. Lebih jauh Pakpahan (2015) menegaskan, jambu biji Kristal Taiwan ini banyak dibudidayakan di Indonesia karena memiliki kelebihan dari jambu-jambu biji yang lainnya, seperti unggul dalam cita rasa yang segar, manis, kres, berdaging tebal dan hampir tanpa biji, mudah dibudidayakan, frekuensi panen yang tinggi, peluang wirausaha yang tinggi baik buah dan pembibitan.

Kabupaten Banyuwangi memiliki nilai kontribusi produksi jambu biji terhadap total produksi jambu Jawa Timur sebesar 5,98\%, atau menduduki peringkat ke-7 dalam share-nya. Namun demikian Kabupaten Banyuwangi tercatat sebagai salah satu kabupaten yang cukup serius dalam mengembangkan budidaya jambu biji, khususnya "jambu biji kristal". Pengembangan jambu biji kristal di Banyuwangi juga mendapatkan perhatian khusus dari DPRD Provinsi Jawa Timur. Sebagaimana dinyatakan oleh DPRD Provinsi Jawa Timur (2019), jambu biji jenis jambu biji kristal diharapkan kedepannya dapat menjadi salah satu komoditas unggulan Kabupaten Banyuwangi dan dapat dijadikan sebagai salah satu produk ekspor Kabupaten Banyuwangi. 
Beritajatim.com

menyatakan, Dinas Pertanian, Kehutanan, dan Perkebunan Kabupaten Banyuwangi sangat berkeinginan menjadikan jambu biji Kristal sebagai komduditas unggulan Kabupaten Banyuwangi. Oleh karena itu jambu biji kristal selalu dimasukkan dalam jajaran buah vestival dalam acara-acara vestival buah lokal Kabupaten Banyuwangi. Disamping itu pengembangan jambu biji Kristal adalah peluang pasar yang cukup bagus dan potensi alam Kabupaten Banyuwangi yang mendukung untuk pengembangan komoditas jambu biji Kristal tersebut.

Kompas.com, (2015) meyakinkan, pada tahun 1998 petani di Banyuwangi, terutama di Kecamatan Tegalsari, mulai membudidayakan jambu biji kristal. Awal pemasaran jambu biji kristal ini, banyak sekali mendapat penolakan dari pedagang, karena harga yang beli yang cukup mahal dan takut tidak ada yang membeli karena buah ini masih baru. Namun seiring berjalannya waktu, banyak masyarakat yang telah mengetahui keberadaan jambu biji Kristal, semakin banyak permintaan jambu biji kristal di pasaran. Saat ini dengan banyaknya permintaan pasar yang tinggi terhadap jambu biji kristal, banyak petani di Banyuwangi yang membudidayakan jambu biji kristal.
Sebagaimana dinyatakan oleh DPRD Provinsi Jawa Timur (2019), dewasa ini jambu biji Kristal sudah dikembangkan di beberapa wilayah kecamatan yang ada di Kabupaten Banyuwangi, diantaranya di kecamatan: (1) Tegalsari, (2) Muncar, (3) Srono, (4) Purwoharjo, dan (5) Cluring. Dimana berdasarkan informasi dari pihak Dinas Pertanian Kabupaten Banyuwangi (2020), dewasa ini jumlah petani jambu biji kristal paling banyak ada di wilayah Kecamatan Purwoarjo. Di wilayah Kecamatan Purwoharjo ini jambu biji kristal dikembangkan di Desa Sidorejo. Para petani jambu biji kristal di Desa Sidorejo ini sebelumnya membudidayakan jambu biji merah, namun kemudian mengganti tanaman jambu biji merahnya dengan jambu biji kristal. Hal ini terjadi karena pertimbangan harga jambu biji kristal di pasaran jauh lebih mahal dari harga jambu biji merah.

Sebagaimana dinyatakan oleh Elvan (2017), pengembangan usahatani jambu biji kristal di Desa Sidorejo menjadi suatu fenomena yang menarik, dimana sebelumnya petani mengusahakan jambu biji merah, selanjutnya beralih pada usahatani jambu biji kristal. Namun demikian pengembangan usahatani jambu biji kristal di Desa Sidorejo, terbilang juga 
sudah cukup baik. Dimana ditinjau dari aspek kelayakan usahatai secara teknis layak, dan secara menyeluruh usahatani yang dilakukan mulai dari aspek lokasi usahatani, skala operasi, layout, dan manajemen budidaya usahatani secara keseluruhan layak.

Dewasa ini terdapat sebanyak 32 orang petani jambu biji kristal di Desa Sidorejo. Adapun produk jambu biji kristal dari Desa Sidorejo sudah merambah ke berbagai pasar. Pasar untuk produksi jambu biji kristal dari Desa Sidorejo tersebar mulai: (a) pasar lokal Banyuwangi, (b) pasar luar kota dalam provinsi, hingga (c) pasar luar kota luar provinsi. Pasar di luar kota dalam provinsi, diantaranya berada di wilayah kabupaten: Surabaya, Malang, dan Jember. Pasar luar kota luar provinsi diantaranya ada di: Pulau Bali, Semarang, Solo, Yogyakarta, dan Jakarta. Pada saat masa pandemi pemasaran jambu biji kristal juga ikut terpengaruh, dimana pemasaran jambu biji kristal menjadi terhambat di beberpa kota dan pemasaran jambu biji kristal di Desa Sidorejo tertuju pada pasar di daerah Pulau Bali, dan Provinsi Jateng.

Jambu biji kristal di Desa Sidorejo digolongkan menjadi buah dengan grade dan tidak. Buah dengan grade dibedakan menjadi dua kelas yaitu grade A dan grade
B. Buah jambu biji kristal dibedakan menjadi diberikan grade dan tidak tergantung lembaga pemasaran yang hendak membeli jambu biji kristal ditingkat petani. Buah jambu biji kristal di di desa sidorejo memiliki harga yang cukup berfluktuatif. Jambu biji kristal yang tanpa grade di tingkat petani memiliki harga Rp.3.000 - Rp.5.000 per Kg. Sedangkan untuk di tingkat konsumen yang ada di Pulau bali hingga mencapai Rp.9.700 per Kg. Harga jambu biji kristal dengan pemberian grade pada grade A harga ditingkat petani adalah Rp.3.000 Rp.6.500 dan ditingkat konsumen pasar luar kota luar provinsi seperti di Pulau Bali dan Semarang hingga mencapai Rp.10.071 per Kg. Sedangkan untuk grade B pada tingkat petani harga jambu biji kristal adalah Rp.1.500 - Rp.3.000 per Kg, dan pada tingkat konsumen harga jambu biji kristal grade B bisa mencapai Rp.7.800 per $\mathrm{Kg}$.

Berdasarkan keadaan diatas terdapat kesenjangan harga yang cukup tinggi pada pemasaran jambu biji kristal di Desa Sidorejo antara harga yang diterima petani sebagai produsen dan harga yang dibayarkan oleh konsumen akhir. Mencermati fenomena tersebut, maka dipandang perlu dilakukannya penelitian guna mengetahui : (a) saluran pemasaran 
jambu biji kristal, (b)margin pemasaran yang paling kecil (c) nilai farmer share yang paling besar, (d) saluran pemasaran jambu kristal yang paling menguntungkan,

\section{METODE PENELITIAN}

Penentuan lokasi dilakukan secara purposive method atau dilakukan dengan sengaja. Pertimbangan yang dilakukan adalah di Desa Sidorejo Kecamatan Purwoharjo usahatani jambu kristal sudah layak dilaksanakan berdasarkkan penelitian oleh Elvan pada tahun 2017, dan juga pasar jambu kristal di Desa Sidorejo yang sudah merambah ke luar kota hingga luar provinsi.

Penelitian ini menggunakan metode deskriptif untuk menjelaskan saluran pemasaran, dan metode analitik untuk menganalisis marjin pemasaran, nilai farmer share, share keuntungan, dan efisiensi pemasaran. Pengambilan sampel dilakukan dengan menggunakan metode total sampling pada responden petani dengan jumlah 32 orang petani, dan purposive method untuk menentukan jumlah lembaga pemasaran.

Saluran pemasaran dianalisis dengan mendeskripsikan saluran pemasaran yang terbentuk di Desa Sidorejo Kecamatan Purwoharjo. Marjin pemasaran dianalisis menggunakan analisis marjin pemasaran. (e) saluran pemasaran yang paling efisien pada saluran pemasaran jambu biji kristal di Desa Sidorejo Kecamatan Purwoharjo kabupaten Banyuwangi Tujuan penggunaan analisis ini yaitu untuk melihat distribusi marjin yang ada pada pemasaran jambu biji kristal secara matematis. Dimana penghitungan marjin pemasaran dapat dirumuskan sebagai berikut (Sudiono, 2002).

$$
\mathbf{M P}=\mathbf{P r}-\mathbf{P f}
$$

\section{Keterangan :}

MP = Marjin Pemasaran jambu biji kristal

Pr = Harga ditingkat pengecer (retail price) jambu biji kristal

Pf = Harga ditingkat petani (farm gate price) jambu biji kristal

Kriteria yang digunakan untuk pengambilan keputusannya melihat dari besar kecilnya marjin yang ada. Jadi semakin kecil nilai marjin pemasaran maka pemasaran tersebut semakin efisien.

Metode yang digunakan untuk mencapai tujuan ketiga tentang nilai farmer share atau keuntungan yang diterima oleh petani adalah menggunakan metode perhitungan nilai farmer share yang mana dapat dirumuskan sebagai berikut :

$$
\text { Fs }=\frac{P f}{P r} \times 100 \%
$$

Keterangan : 
Fs = Farmer's Share atau bagian

harga yang diterima petani jambu biji

kristal

Pf = Harga yang diterima oleh petani

jambu biji kristal

$\operatorname{Pr} \quad=$ Harga yang dibayarkan oleh

konsumen

Kriteria pengambilan keputusan :

Semakin tinggi nilai Farmer's Share maka semakin tinggi keuntungan yang diterima petani.

Metode yang digunakan untuk mencapai tujuan mengetahui besaran keuntungan pada setiap lembaga pemasaran dihitung dengan menggunakan metode Analisis share Biaya, dan share keuntungan. metode Analisis share Biaya, dan share keuntungan dapat dirumuskan sebagai berikut :

$\begin{array}{ll}\text { Share Biaya } & : \text { Sbij }=(\mathrm{Cij} / \mathrm{Pr}) \mathrm{x} \\ 100 \% & \mathrm{Cij}=\mathrm{HJj}-\mathrm{HBj}- \\ & \end{array}$

$\pi \mathrm{ij}$

$$
\begin{gathered}
\operatorname{Sbij}=(C i j /(P r-P f)) \times 100 \% \\
C i j=H J j-H B j-\pi i j
\end{gathered}
$$

Share Keuntungan $: \mathrm{SKj}=(\pi \mathrm{ij} / \mathrm{Pr}) \mathrm{x}$ $100 \%$

$$
\Pi \mathrm{ij}=\mathrm{HJj}-\mathrm{HBj}-
$$

$\mathrm{Cij}$

$$
\begin{gathered}
\mathrm{SKJ}=(\pi \mathrm{ij} /(\mathrm{Pr}-\mathrm{Pf})) \times 100 \% \\
\Pi \mathrm{ij}=\mathrm{HJj}-\mathrm{HBj}-\mathrm{Cij}
\end{gathered}
$$

Keterangan :

Sbij = bagian biaya untuk fungsi

pemasaran ke - i oleh lembaga pemasaran

ke j

Cij = biaya untuk fungsi pemasaran ke

- i oleh lembaga pemasaran ke - j

Pr = harga yang dibayarkan oleh

konsumen

Pf = harga yang diiterima oleh petani jambu biji kristal

Hij = harga jual jambu biji kristal lembaga pemasaran ke $\mathrm{j}$

$\mathrm{Hbj} \quad=$ harga beli jambu biji kristal lembaga pemasaran ke $\mathrm{j}$

$\pi \mathrm{ij}=$ keuntungan lembaga pemasaran ke j

Skj = bagian keuntungan lembaga pemasaran ke $\mathrm{j}$

Kriteria pengambilan keputusan :

a. Jika Ski > Sbi maka saluran pemasaran Jambu biji kristal menguntungkan.

b. Jika Ski < Sbi maka saluran pemasaran Jambu biji kristal tidak menguntungkan.

Metode yang digunakan untuk tujuan kelima tentang efisiensi pemasaran adalah analsisis efisiensi pemasaran. Menurut Soekartawi (1989), efisiensi pemasaran merupakan perbandingan antara 
biaya total dengan total nilai produk yang dipasarkan, dimana dapat dirumuskan sebagai berikut :

$$
\mathbf{E P}=\frac{T B}{T N P} \times 100 \%
$$

Keterangan:

$\mathrm{EP} \quad=$ Efisiensi Pemasaran jambu biji kristal

$\mathrm{TB}=$ Total Biaya jambu biji kristal

$\mathrm{TNP}=$ Total Nilai Produk jambu biji

kristal
Kriteria pengambilan keputusan yang digunakan untuk melihat efisiensi pemasaran yaitu apabila nilai efisiensi pemasaran sebesar $0 \%$ - 50\%, maka saluran pemasaran tersebut dinyatakan efisien. Sedangkan apabila nilai efisiensi pemasaran memiliki nilai $>50 \%$, maka saluran pemasaran dinyatakan belum efisien

\section{HASIL DAN PEMBAHASAN}



\section{Gambar 1. Kerangka saluran pemasaran jambu kristal di Desa Sidorejo Kecamatan Purwoharjo Kabupaten Banyuwangi}

Saluran pemasaran 1 melibatkan beberapa lembaga pemasaran yaitu pengepul, pedagang besar, dan pedagang pengecer. Saluran pemasaran 1 memiliki jumlah 10 petani yang memasarkan buah jambu kristal. Alasan petani memilih menjual jambu kristal melalui saluran pemasaran ini karena hubungan yang sudah terjalin dengan lama. Jadi petani lebih merasa aman ketika memasarkan jambu kristalnya karena sudah ada kepercayaan satu sama lain dalam 
memasarkan jambu kristal. Petani memasarkan jambu kristal melalui pengepul sebagai lembaga pemasaran yang membeli jambu kristal langsung dari petani.

Saluran pemasaran 2 jambu kristal melalui beberapa lembaga pemasaran. Mulai dari pedagang besar, agen, dan pedagang pengecer. Pada saluran pemasaran dua petani menjual jambu kristal miliknya tanpa melalui perantara pengepul melainkan langsung menjualnya pada pedagang besar. Alasan petani memilih saluran pemasaran ini karena agen atau pengirim lebih bisa menerima hasil panen jambu kristal berapapun jumlahnya. Dibandingkan dengan pengepul terkadang ketika memasuki panen raya dan jumlah jambu melimpah tidak semua pengepul mau menerima hasil panen petani. Petani yang memasarkan jambu kristal pada saluran 2 berjumlah 10

Saluran pemasaran terakhir yang termasuk pada saluran pemasaran model B adalah saluran pemasaran 3. Saluran pemasarann 3 merupakan saluran pemasaran terpendek yang ada pada saluran pemasaran jambu kristal di Desa
Sidorejo. Dimana petani langsung menyalurkan jambu kristal yang diproduksi ke pedagang besar. Petani yang memasarkan jambu kristal pada saluran ini berjumlah 5 petani. Harga jambu kristal yang diberikan agen atau pengirim adalah Rp.3000 sampai Rp.6000 untuk grade A dan untuk grade $\mathrm{B}$ setengah harga dari grade A.

saluran pemasaran 4 melibatkan lembaga -lembaga pemasaran mulai dari pengepul, pedagang besar, dan pedagang pengecer. Pada saluran pemasaran 4 terdapat 5 petani yang menjual jambu kristal melalui saluran pemasaran ini. Pada saluran pemasaran 4 pedagang pengepul tidak membedakan grade buah dalam pembelian di petani. Dimana pengepul membeli jambu kristal dari petani dengan harga Rp. 3000 - Rp.5000 untuk semua buah baik dengan ukuran, permukaan, dan kualitas yang berbeda. Petani yang memilih saluran 4 memang beralasan hal tersebut sehingga menentukan saluran 4 sebagai saluran pemasaran jambu kristalnya. 
Tabel 1 Marjin Pemasaran Jambu Kristal di Desa Sidorejo Kecamatan Purwoharjo Kabupaten Banyuwangi.

\begin{tabular}{lccc}
\hline No & Saluran Pemasaran & \multicolumn{2}{c}{ Grade } \\
\hline Saluran Pemasaram Model B & Grade A & Grade B \\
$\mathbf{1} \quad$ Sluran Pemasaran 1 & 5.500 & 5.500 \\
$\mathbf{2}$ & Sluran Pemasaran 2 & 7.500 & 7.500 \\
$\mathbf{3} \quad$ Sluran Pemasaran 3 & 5.500 & 5.500 \\
Saluran Pemasaram Model A & & \\
$\mathbf{4} \quad$ Sluran Pemasaran 4 & \multicolumn{2}{c}{5.500} \\
\hline
\end{tabular}

hasil analisis menunjukkan bahwa ada 2 marjin pemasaran, yaitu marjin pemasaran sebbesar Rp.5.00 dan Rp.7.500. Berdasarkan analsisis marjin pemasaran saluran pemasaran jambu kristal marjin pemasaran terkecil adalah Rp.5.500 yang ada pada saluran pemasaran 1, saluran pemasaran 3, dan saluran pemasaran 4 . Dimana pada saluran pemasaran tersebut nilai marjin pemasaran paling kecil, sehingga saluran pemasaran tersebut paing efisien.

Tabel 2. Nilai Farmer Share Pemasaran Jambu Kristal di Desa Sidorejo Kecamatan Purwoharjo Kabupaten Banyuwangi

\begin{tabular}{llcc}
\hline No $\quad$ Saluran Pemasaran & \multicolumn{2}{c}{ Grade } \\
\hline Saluran Pemasaram Model B & Grade A (\%) & Grade B (\%) \\
$\mathbf{1} \quad$ Sluran Pemasaran 1 & 44,72 & 29,49 \\
$\mathbf{2} \quad$ Sluran Pemasaran 2 & 37,50 & 23,08 \\
$\mathbf{3} \quad$ Sluran Pemasaran 3 & 45,39 & 29,36 \\
Saluran Pemasaram Model A & & 43,30 \\
$\mathbf{4} \quad$ Sluran Pemasaran 4 & menjadi saluran pemasaran paling efisien \\
\hline \multicolumn{2}{c}{ Nilai farmer share pada pemasaran } & untuk pemasaran jambu kristal dengan \\
jambu kristal tertinggi ada pada saluran & grade A dan pada saluran pemasaran 1 \\
pemasaran ke 3 untuk jambu kristal grade & menjadi saluran pemasaran paling efisien \\
A yaitu sebesar 45,39\%, dan untuk jambu & untuk memasarkan jambu kristal dengan \\
kristal grade B ada pada saluran & grade B. \\
pemasaran 1 dengan nilai 29,49\%. Jadi &
\end{tabular}

pada saluran pemasaran jambu kristal di

Desa Sidorejo saluran pemasaran ke 3 
Tabel 3. Nilai Share Keuntungan Pemasaran Jambu Kristal di Desa Sidorejo Kecamatan Purwoharjo Kabupaten Banyuwangi

\begin{tabular}{|c|c|c|c|c|c|}
\hline \multirow[t]{3}{*}{ Saluran Pemasaran } & \multicolumn{4}{|c|}{ Grade } & \multirow[t]{3}{*}{ Keterangan } \\
\hline & \multicolumn{2}{|c|}{ Grade A } & \multicolumn{2}{|c|}{ Grade B } & \\
\hline & Sbi $(\%)$ & $\begin{array}{l}\text { Ski } \\
(\%)\end{array}$ & Sbi $(\%)$ & Ski $(\%)$ & \\
\hline \multicolumn{6}{|l|}{$\begin{array}{c}\text { Saluran Pemasaram } \\
\text { Model B }\end{array}$} \\
\hline Saluran Pemasaran 1 & 15,34 & 84,66 & 19,56 & 80,44 & Menguntungkan \\
\hline Saluran Pemasaran 2 & 21,59 & 78,41 & 26,57 & 73,43 & Menguntungkan \\
\hline Saluran Pemasaran 3 & 12,90 & 87,10 & 16,68 & 83,32 & Menguntungkan \\
\hline $\begin{array}{l}\text { Saluran Pemasaram } \\
\text { Model A }\end{array}$ & \multicolumn{2}{|c|}{ Sbi } & \multicolumn{2}{|c|}{ Ski } & \\
\hline Saluran Pemasaran 4 & \multicolumn{2}{|c|}{14,08} & \multicolumn{2}{|c|}{85,92} & Menguntungkan \\
\hline
\end{tabular}

Berdasarkan hasil analisis apda

tabel 3. secara keseluruhan saluran pemasaran jamu kristal di Desa Sidorejo dinyatakan menguntungkan, karena dari ke empat saluran nilai share keuntungan lebih besar dari nilai share biaya (Ski>Sbi).
Nilai keuntungan terbesar berada pada saluran pemasaran ke 3 dengan selisih antara nilai share biaya dan share keuntungan sebesar $74,2 \%$ untuk pemasaran jambu kristal pada grade A.

Tabel 4. Nilai Efisiensi Pemasaran Jambu Kristal di Desa Sidorejo Kecamatan Purwoharjo Kabupaten Banyuwangi

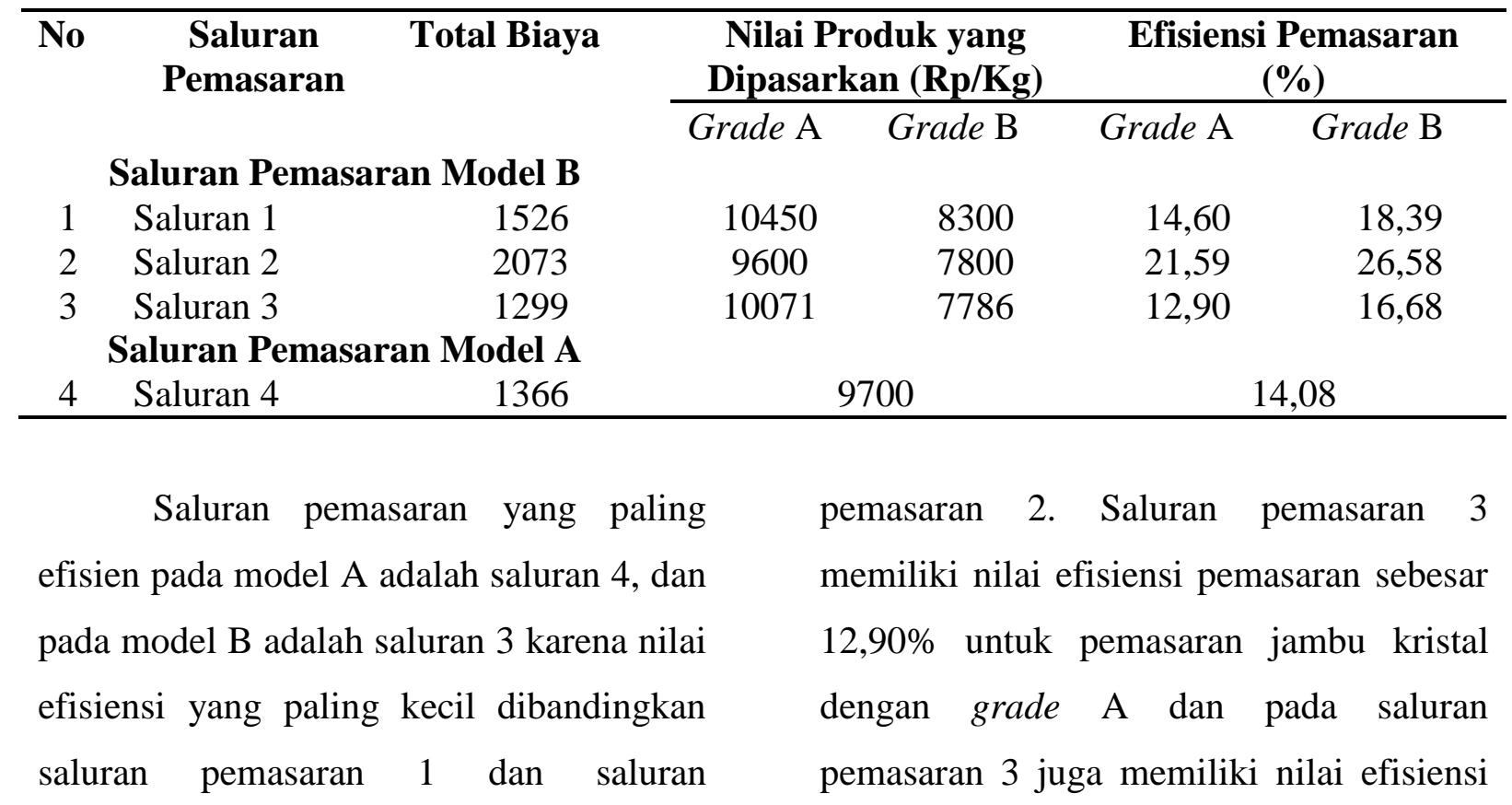


salurann pemasaran terkecil pada grade $\mathrm{B}$

\section{KESIMPULAN DAN SARAN}

1. Saluran pemasaran jambu kristal di Desa Sidorejo Kecamatan Purwoharjo Kabupaten Banyuwangi terdiri dari 2 model saluran pemasaran yaitu saluran model A dan model B. saluran Pemasaran model A terdiri dari 1 saluran (saluran pemasaran 4) dan saluran model B terdiri dari 3 saluran (saluran 1, saluran 2, saluran 3)

2. Berdasarkan analsisis marjin pemasaran saluran pemasaran jambu kristal marjin pemasaran terkecil adalah Rp.5.500 yang ada pada saluran pemasaran 1 , saluran pemasaran 3 , dan saluran pemasaran 4 .

3. Nilai farmer share pada pemasaran jambu kristal tertinggi ada pada

\section{DAFTAR PUSTAKA}

Andayani, S. A., Adet, S., dan Ferdiana, A. 2014. Analisis Tataniaga DalamUsahatani Jambu Kristal (Psidium Guajava L) Suatu Kasus di Desa Jayi Kecamatan Sukahaji Kabupaten Majalengka. Ilmu Pertanian dan Peternakan. 2(2): 8-32.

Darmayanti, N. T. 2016. Potensi Pengembangan tanaman Jambu Krisatal (Psidium Guajava L.) Berdasarkan Aspek Agroklimat di Jawa Barat . Skripsi. Bogor: Pertanian Insitut Pertanian Bogor. dengan nilai $\quad 16,68 \%$.

saluran pemasaran ke 3 untuk jambu kristal grade A yaitu sebesar 45,39\%, dan untuk jambu kristal grade $\mathrm{B}$ ada pada saluran pemasaran 1 dengan nilai $29,49 \%$.

4. Secara keseluruhan saluran pemasaran jamu kristal di Desa Sidorejo dinyatakan menguntungkan, karena dari ke empat saluran nilai share keuntungan lebih besar dari nilai share biaya (Ski>Sbi).

5. Saluran pemasaran yang paling efisien pada model A adalah saluran 4, dan pada model B adalah saluran 3 karena nilai efisiensi yang paling kecil dibandingkan saluran pemasaran 1 dan saluran pemasaran 2 .

DPRD Provinsi Jawa Timur. 2019. DPRD Dorong Pemerintah Beri Perhatian Jambu Kristal Banyuwangi. http://dprd.jatimprov.go.id/berita/i d/9513/dprd-dorong-pemerintahberi-perhatian-jambu-kristalbanyuwangi. (Diakses pada 15 November 2019

Hadiati, S., dan Apriyanti, L. H. 2015. Bertanam Jambu Biji di Pekarangan. Agriflo : Jakarta

Kompas. 2015. Festival Buah Lokal, Daya Tarik Baru Banyuwangi. https://travel.kompas.com/read/20 15/03/30/124300227/Festival.Bua 
h.Lokal.Daya.Tarik.Baru.Banyuw angi. (Diakses Pada 15 November 2019)

Parimin, 2005. Jambu Biji. Budi Daya dan Ragam Pemanfaatannya. Jakarta Penebar Swadaya.

Soekartawi. 1989. Prinsip Dasar Ekonomi Pertanian. Jakarta: rajawali

Sudiyono, Armand. 2002. Pemasaran Pertanian. Malang: Universitas Muhammadiyah Malang.
Wiraatmaja, I.W., Rai, I. H, dan Mahendra, I. Gi. J. 2017. Upaya Meningkatkan Produksi dan Kualitas Buah Jambu Biji Kristal (Psidium Guajava L.) Melalui Pemupukan. Agrotop. 7(1): 60-68

Wiraatmaja, I. W. 2017. Budidaya Jambu Biji Kristal (Psidium Guajava L.). Bahan Ajar. Denpasar : Fakultas Pertanian Universitas Udayana Program Studi Agrotekknologi. 